\title{
Do Refuge Chambers Represent a Good Strategy to Manage Emergencies in Underground Coal Mines?
}

\author{
A. E. Halim ${ }^{1}$. J. F. Brune ${ }^{2}$ \\ Received: 29 October 2018 / Accepted: 12 June 2019 / Published online: 25 June 2019 \\ (C) The Author(s) 2019
}

\begin{abstract}
The 2006 Sago, Darby, and Aracoma mine disasters in the United States (US) forced the US government to implement the 2006 MINER Act and additional regulations that require all US underground coal mines to install and maintain refuge chambers to manage entrapment emergencies, in particular, fires and explosions. However, there is a debate on whether barricading in refuge chambers is a good strategy to survive such emergencies. Australian coal mines are not required to use refuge chambers and, instead, have adopted a strategy that focuses on instructing and training miners to self-escape to the surface. This paper analyzes merits and problems of using refuge chambers and self-escape to the surface to manage emergencies in fires or explosions in an underground coal mine. The authors found that the use of refuge chambers may not be the best strategy during extensive fires or when multiple explosions happen. In these situations, mine rescuers are unlikely able to extract miners who are sheltered in chambers and conversely, self-escape may save more lives than sheltering. Chances for successful self-escape are further improved by regular, externally assessed training such as Level 1 Emergency Exercises required in the Australian State of Queensland. These exercises put pressure on mine operators to ensure and maintain the effectiveness of their emergency management system.
\end{abstract}

Keywords Refuge chamber $\cdot$ Mine emergency $\cdot$ Mine fire $\cdot$ Underground coal mines

\section{Introduction}

On 2 January 2006, a methane-air explosion occurred inside a sealed, mined-out area at the Sago coal mine in the State of West Virginia, USA. Twelve miners perished in this disaster. Following this, the United States (US) government implemented regulation 30 CFR $\$ 75.1506$ and accompanying rules that require all US coal mining companies to install and maintain refuge chambers in their underground mines to manage mine emergencies where miners may be trapped underground. Refuge chambers have long been used in underground hard rock mines, where trapped miners can go to the nearest refuge chamber and shelter there until the hazard is no longer present and/or mine rescue teams extract them and bring them back to

\section{A. E. Halim}

adrianus.halim@ltu.se

1 Luleå University of Technology, Luleå, Sweden

2 Colorado School of Mines, Golden, CO, USA the surface. Miners who are able to safely escape to the surface are trained to do so, rather than going to a refuge chamber.

A refuge chamber is a stationary or movable/mobile chamber where miners take refuge during entrapment emergencies such as fires, explosions, roof falls, and inundations. The chambers provide the miners with 96 or more hours of full life support including breathable air, food, water, and waste disposal. Many stationary and some movable chambers are equipped with air conditioning as well. Stationary or "inplace" chambers typically have permanent and independent power and voice communications, compressed air supply lines and, in some cases, a supply borehole to the surface where food, water, medications etc. can be supplied to the trapped miners. Movable chambers can have independent power and voice communications that are powered by battery. Supply boreholes can extend life support beyond the typical 96-h self-supported limit. Unless other provisions are available, miners must be rescued from the chamber within this period.

Fires in underground coal mines can be far more hazardous than those in underground hard rock mines as the coal itself is a fuel source that can support fires for months and even years. 
In hard rock mines, fuel sources are limited: A typical piece of equipment will only burn for a few hours until fuel, tires, and other combustibles are consumed. Another hazard common to coal mines is the presence of methane which often accumulates in explosive concentrations when the ventilation system is compromised, a common issue during mine fires and explosions.

If coal mine refuge chambers contain electrical components, these must be constructed to meet coal mine permissibility standards for explosion prevention. US regulation 30 CFR $\S 7.505$ requires that coal mine chambers must be able to withstand an explosion overpressure of 1 atmosphere (15 psi) for 0.2 seconds prior to deployment as well as a flash fire of $150^{\circ} \mathrm{C}\left(300^{\circ} \mathrm{F}\right)$. In the USA, hard rock mine refuge chambers do not have these requirements.

Not all underground coal mines worldwide use refuge chambers to manage fire or explosion emergencies. Australian regulations do not require refuge chambers in coal mines. Australian mining industry strategy focuses on instructing all miners to self-escape to the surface in these emergencies although there is still a debate whether these mines should use refuge chambers like in the USA. It has to be noted that this strategy is promoted as the primary strategy in coal mines emergencies by the National Institute of Occupational Safety and Health (NIOSH), a US government agency that focuses on workers' safety and health, and Mine Safety and Health Administration (MSHA), a US government agency that develops and enforces safety and health rules for all US mines. Both agencies recognize that the use of refuge chambers is a "last resort."

Another place where miners can take refuge is barricading. In US coal mines, barricading was taught as a method to shelter trapped miners until 2006. The authors learned that barricading did not work during 2006 Sago explosion. Eleven miners died of $\mathrm{CO}$ poisoning after barricading. Even if a barricade is airtight and erected in fresh air, miners will eventually succumb to $\mathrm{CO}_{2}$ asphyxiation.

\section{Differences Between Fires in Underground Hard Rock and Coal Mines}

In order to start analyzing the two emergency management strategies, the authors looked at differences between fires in underground hard rock and coal mines, as shown in Table 1.

Table 1 shows that fires in underground hard rock mines are less hazardous and short-lived compared with those in underground coal mines. Fires in underground hard rock mines are easier to manage. When one of the authors was working in a gold mine in Kalgoorlie-Boulder in Australia in 2008-2011, there were three truck fires. All of them were extinguished within $30 \mathrm{~min}$, and all miners managed to reach refuge chambers. They were extracted by the mine rescue team within $1 \mathrm{~h}$. Extraction by a rescue team is mandated in Australian hard rock mines even though miners may be able to self-escape after the fire is out and ventilation has been restored.

In coal mines, a fire can be difficult or impossible to extinguish as the burning coal itself may supply sufficient oxygen to sustain a smoldering fire for years and decades even if mine management is successful in flooding the mine with water or inert gases. Following are examples of coal fires that have been lasting for years:

- Mount Wingen in the State of New South Wales in Australia. The coal seam located $30 \mathrm{~m}$ below the surface is believed to have been burning for 6000 years [1].

- Centralia coal fire in the State of Pennsylvania in the USA. The fire was accidentally ignited when the residents of the town of Centralia burned trash in a nearby former open cut coal mine on 27 May 1962. The outcropping coal seam was ignited, and despite many efforts to extinguish it, it is still burning until this day. Eventually, the town of Centralia had to be abandoned [2,3].

- Brennender Berg (burning mountain) in the State of Saarland, Germany. The coal seam underneath it is believed to have been smoldering since the midseventeenth century and may have been ignited by spontaneous combustion [4].

The differences between fires in underground hard rock and coal mines have a significant impact on the feasibility of using refuge chambers in both mines. Using refuge chambers may be a successful strategy in hard rock mines because fires are short-lived and miners can exit the mine as soon as the fire is out and the mine air quality has been restored through ventilation. The long-term fire and explosion hazard in coal mines makes it much riskier to seek refuge and await rescue, bearing the question whether miner should use refuge chambers in coal mines at all.

Figure 1 shows an example of a 12-person, movable refuge chamber for a hard rock mine. This chamber is tall enough for miners to stand upright inside. The chamber width is matching the drift size in hard rock mines, typically 4 to $6 \mathrm{~m}$.

Figure 2 shows an example of a 12-person, movable refuge chamber for a coal mine. Chambers for use in coal mines may be lower in mines with lower entry heights. Often, coal chambers are also wider as rectangular coal mine entries are typically 5 to $6 \mathrm{~m}$ wide.

\section{Discussion on Using Refuge Chambers in Underground Coal Mines}

During a mine fire or in a mine atmosphere contaminated by explosion gases, miners protect their lives by using $\mathrm{CO}$ filter 
Table 1 Differences between fires in underground hard rock and coal mines

\begin{tabular}{ll}
\hline Hard rock mines fires & Coal mines fires \\
\hline $\begin{array}{c}\text { Limited amount of combustible material (diesel fuel, } \\
\text { tires, explosives, lubricants) }\end{array}$ & $\begin{array}{c}\text { Virtually unlimited amount of combustible material } \\
\text { (coal) in addition to diesel fuel, lubricants, tires, } \\
\text { conveyor belting, and explosives }\end{array}$ \\
$\begin{array}{c}\text { Due to limited amount of combustible material, fire } \\
\text { will extinguish itself after several hours. }\end{array}$ & $\begin{array}{c}\text { Due large amount of combustible material, fire can } \\
\text { last months or years } \\
\text { Low or no explosion risk unless there is methane } \\
\text { present, for example, in certain trona, potash, salt, } \\
\text { and gold mines }\end{array}$ \\
\hline
\end{tabular}

self-rescuers that do not provide oxygen, self-contained selfrescuers (SCSR) with bottled or chemical oxygen, or compressed air breathing apparatus (CABA). Most current devices provide breathing support for one (1) hour and must be exchanged or re-charged before their capacity expires. Depending on the conditions of the underground walkways, doors, stairs and grades to be negotiated, available height, and physical condition of the miners, the walkable distance during this hour may vary. A study by Kovac et al. [7] shows that the probability of survival drops drastically as the escape distance exceeds $2000 \mathrm{~m}$. The study evaluates and includes the time miners need to don their rescue breathing apparatus and accounts for other difficulties encountered during the escape, including decision-making, choice of escape routes, and group dynamics. Consequently, US regulation $30 \mathrm{CFR}$ $\$ 75.1506$ requires that the first refuge chamber must be installed within $300 \mathrm{~m}$ from the mining face. This requirement necessitates the use of movable chambers because the face can advance by $30 \mathrm{~m}$ per day. Additional chambers must be provided within $1-\mathrm{h}$ travel distances along the escape route so that no miner is more than $30 \mathrm{~min}$ away from a refuge chamber at any given time.

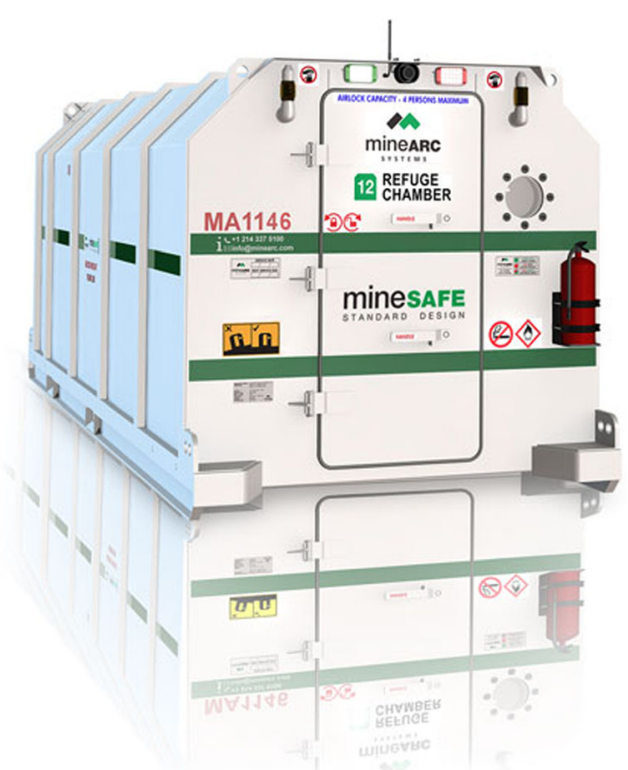

Fig. 1 A hard rock mine refuge chamber [5]
MSHA regulations require refuge chambers to support life for at least $96 \mathrm{~h}$. During a fire or if explosion hazards are present, there is a possibility that the mine rescue teams are unable to enter the mine and rescue the miners from the refuges. For example, multiple secondary explosions prevented rescue during the Moura No. 2 disaster in the State of Queensland, Australia in 1994 [8] and the Pike River disaster in New Zealand in 2010 [9]. In both cases, authorities decided that the conditions were too dangerous for mine rescue teams to enter the mines. Authorities subsequently decided to seal both mines, leaving the bodies of the deceased miners buried underground.

In situations like Moura No. 2 and Pike River, refuge chambers may not be the best strategy. It can be argued that, in other disasters, such as Sago and Upper Big Branch, the

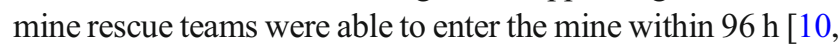
11]. However, in the Upper Big Branch case, most miners close to the longwall died instantly from direct explosion and burn trauma or from $\mathrm{CO}$ exposure and were unable to enter refuge chambers. Eight miners tried to escape by rail but their mantrip got stuck in debris from the explosion and seven miners were overcome with $\mathrm{CO}$; the 8 th miner was able to walk out. These seven miners might have survived had they been able to shelter in a refuge chamber. Likewise, the disasters in Australia and New Zealand demonstrate that there is a likelihood that miners may not be able to enter a refuge

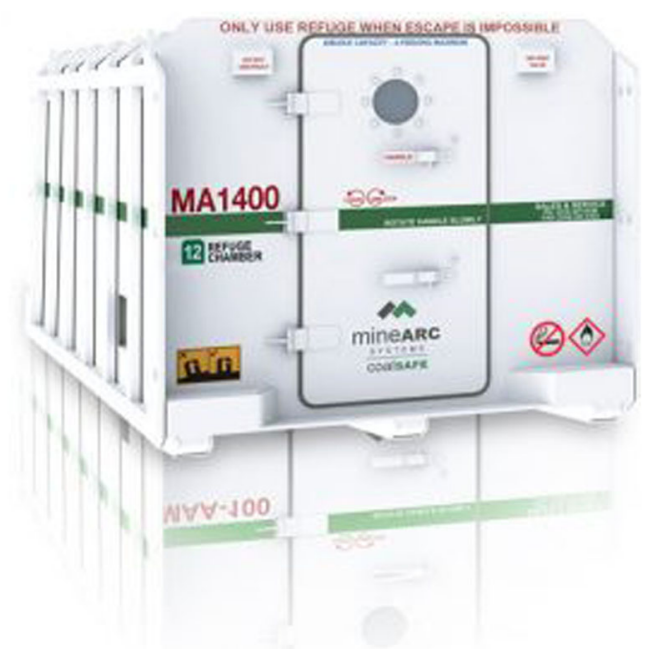

Fig. 2 A coal mine refuge chamber [6] 
chamber and, more so, mine rescue teams may be unable to enter the mine to rescue sheltered miners.

Besides these concerns, there are several other issues that question the feasibility of using refuge chambers to manage emergencies in underground coal mines. These issues will be discussed next.

\subsection{Resistance to Withstand Fires and Explosions}

US refuge chambers must be designed to withstand explosion pressure up to $15 \mathrm{psi}(100 \mathrm{kPa})$. If a free-standing chamber with a cross-sectional area of $4 \mathrm{~m}^{2}$ is unilaterally exposed to such an explosion pressure, this pressure may briefly exert a force of $400 \mathrm{kN}$ on the chamber. In full-scale mine explosion tests, Weiss et al. [12] subjected a 700-kg battery charger to a static pressure of approximately $200 \mathrm{kPa}$. The charger had a cross-section area of approximately $1 \mathrm{~m}^{2}$, which means that it was subjected to a force of $200 \mathrm{kN}$, and was thrown a distance of $24 \mathrm{~m}$. This experiment raises questions about the ability of any refuge chamber, particularly a movable chamber, to withstand direct impact from a mine explosion.

The US Army Corps of Engineers carried out a computational fluid dynamics (CFD) simulation of the Sago mine explosion. The simulations estimate that the pressure in an entry outby the seal location is higher than $50 \mathrm{psi}(345 \mathrm{kPa})$ [13]. Zipf et al. [14] analyzed pressure measurements of experimental mine explosions in the USA, Germany, and Poland. These results show that coal mine explosions can generate pressures greater than $145 \mathrm{psi}(1 \mathrm{MPa})$. At such high pressures, there is a likelihood that both stationary or movable chambers will be destroyed in a mine explosion.

Research by Zipf et al. [15] and Strebinger et al. [16] indicates that explosion flow through room-and-pillar mines will increase turbulence, thereby raising the flame velocity and explosion pressures. Explosions traveling through multiple entries like room-and-pillar entries and crosscuts are far more destructive than explosions propagating along single entries.

\subsection{Maintaining a Breathable Atmosphere Inside the Chamber}

Refuge chambers are typically equipped with a supply of oxygen and chemical scrubbers that clean $\mathrm{CO}_{2}$ and $\mathrm{CO}$ from the chamber air. The oxygen supply is designed to make up for human consumption and leakage losses that occur particularly with tent-style chambers. As with all life support, breathing air supplies are designed to last at least $96 \mathrm{~h}$ at full occupancy level.

$\mathrm{CO}_{2}$ and $\mathrm{CO}$ scrubbing can be done with battery-operated fans drawing air through chemical scrubber beds of either soda lime or lithium hydroxide. Other chambers may have passive scrubbing systems that do not require a fan or batteries: curtains filled with the scrubber chemicals that scrub the air through diffusion.
A critical time to establish and maintain chamber air quality is during entry. Although most chambers are equipped with a set of double doors which form an airlock that can be purged, there is a risk of contamination inside the chamber if the mine air contains high concentrations of toxic gases or smoke. Mine rescue teams encountered $\mathrm{CO}$ levels greater than 10,000 ppm (1\%) after the coal dust explosion in the Upper Big Branch mine in 2010 [17]. Assuming that miners enter a refuge chamber in such an atmosphere, they would have to purge the airlock to dilute the $\mathrm{CO}$ concentration by a factor of 400 or more to reach an acceptable air quality of $25 \mathrm{ppm}$ or less $\mathrm{CO}$ inside the main chamber. Bauer et al. [18] studied purging in an experimental airlock chamber, starting with an outside CO concentration of 400 ppm based on MSHA standard 30 CFR $\$ 7.508$. They confirmed that each full volume exchange of the airlock chamber reduces the contaminant concentration by $50 \%$. Thus, for a dilution factor of 400, at least nine purges are required, given that $2^{9}=512$. Figure 3 shows the purge times required at different air flow rates based on the experiments by Bauer et al. [18]. US regulation 30 CFR $\$ 7.508$ establishes a starting CO concentration of $400 \mathrm{ppm}$ for testing and for demonstrating the purging function. Bauer et al. [18] note that the 400 ppm may not be realistic in post-explosion conditions where the $\mathrm{CO}$ level may exceed $1 \%(10,000 \mathrm{ppm})$ or more. They also note that the purging effectiveness is affected by the size and shape of the airlock and the speed with which miners can enter it.

In most chambers, the airlock only has room for $1 / 4$ to $1 / 3$ of the total occupancy. This means miners must enter the chamber in three to four groups. Bauer measured purge times ranging between 9.5 and $20 \mathrm{~min}$ for the four purge cycles required to reduce the $\mathrm{CO}$ concentration from 400 to 25 ppm. If nine purges are needed and assuming each purge takes about $3 \mathrm{~min}$, it would take about $27 \mathrm{~min}$ to get each group of miners through the airlock, while the other miners must wait outside under SCSRs. Note that US regulation $30 \mathrm{CFR} \S$ 7.508 only provides for a 20 -min time frame for all purging cycles to be completed for all occupants of the chamber. Considering these calculations and the measurements taken by Bauer et al., the stipulated $20 \mathrm{~min}$ purge time appears unrealistic. As most SCSRs only provide $1 \mathrm{~h}$ breathing capacity, there must also be a cache of SCSRs next to every chamber to protect miners while they wait to get in. Furthermore, for four teams and nine purges each, 36 purges would be required for all miners to enter the chamber. The authors are not aware of any current refuge chamber that provides air for up to 36 purges so that all miners could safely enter the chamber.

\subsection{Heat Dissipation from the Chamber}

An average human, at rest, produces approximately $117 \mathrm{~W}$ of heat [19] [20]. In addition, the $\mathrm{CO}_{2}$ scrubbing process involves an exothermal chemical reaction that adds 40 to $50 \mathrm{~W}$ per person to the heat generated inside the chamber. 
Fig. 3 Purge times to reduce the CO concentration from 400 to 25 ppm, using three different purge air flow rates [18]

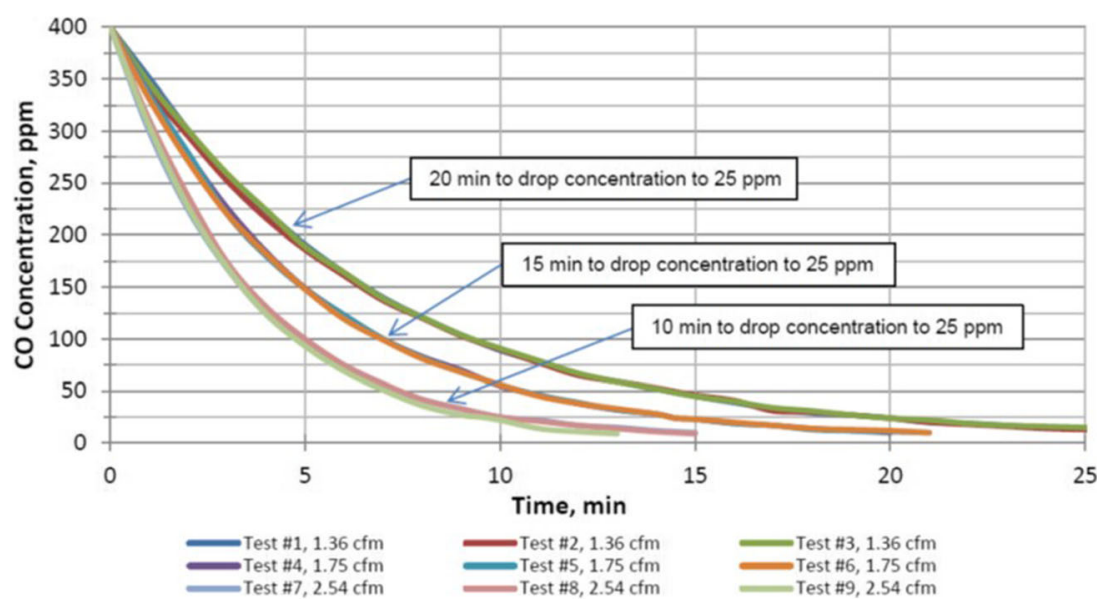

The ability of the chamber to dissipate this heat depends on the temperature of the air and rock inside the mine. MSHA has limited the apparent temperature in mine refuge alternatives to a heat index of 95 based on Steadman [21] (see also US regulation 30 CFR \$7.504). This temperature index is based on a mathematical regression that uses dry bulb temperature and relative humidity as input parameters. At $90 \%$ relative humidity, a Steadman heat index of 95 is reached at a dry bulb temperature of $28.3{ }^{\circ} \mathrm{C}$. Figure 4 shows a graph of the Steadman heat index for a range of temperatures and relative humidities between 80 and $100 \%$.

Physical experiments using a 10-person, tent-style chamber, along with model calculations by Yantek [22], have shown that the occupancy level in a given chamber may need to be de-rated if the ambient temperature in the mine exceeds the maximum design temperature. In an example given by Yantek, no derating is required below $15.5^{\circ} \mathrm{C}$. At $18^{\circ} \mathrm{C}$, the chamber capacity must be reduced by $40 \%$, up to $21{ }^{\circ} \mathrm{C}$ by $60 \%$ and at temperatures up to $24{ }^{\circ} \mathrm{C}$, de-rating by $80 \%$ would be required. Similar de-rating curves were developed by Brune [19] for four different chamber models, as shown in Fig. 5.

Yantek's experiments and Brune's calculations show that the atmosphere inside refuge chambers will reach condensing

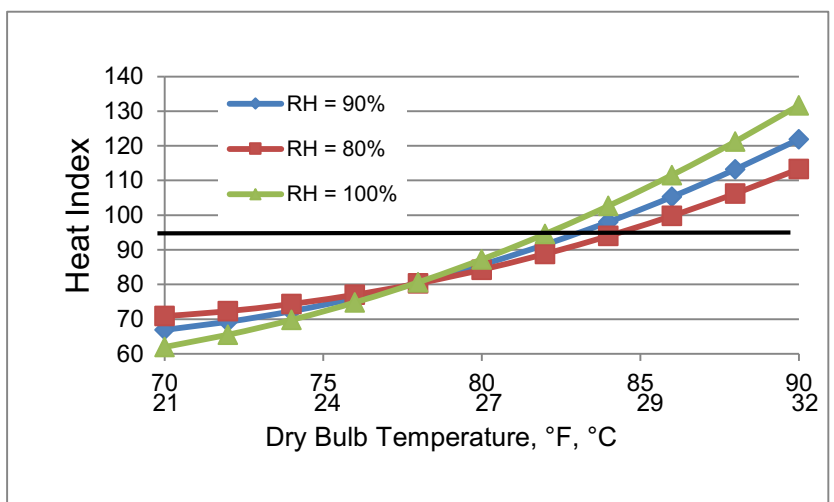

Fig. 4 Graph showing the Steadman heat index, using the equation provided by Steadman [21] condition at relative humidity levels near $100 \%$. Condensed water will pool at the floor of the chamber, which may make conditions uncomfortable especially in tent-style chambers.

Some manufacturers offer movable refuge chambers with cooling and air conditioning. These chambers require battery power but have the advantage that the atmosphere inside the chamber is maintained at a more comfortable humidity.

\subsection{Air Quality Monitoring}

The quality of air inside the chamber must be carefully monitored to maintain oxygen between 18.5 and $23 \%, \mathrm{CO}_{2}$ below $1 \%$, and CO below 10 ppm (30 CFR §7.506). Handheld gas detectors can be used for this purpose but are usually not designed to function in condensing atmospheres or above $95 \%$ relative humidity as condensation may clog or incapacitate the sensors. Most gas sensors, including $\mathrm{CO}$, are limited to a relative humidity below $90 \%$. Electronic circuits may be compromised if operated in humid atmospheres. Yantek [22] demonstrated in experiments that the relative humidity inside the would rise to $93 \%$, which makes it questionable whether

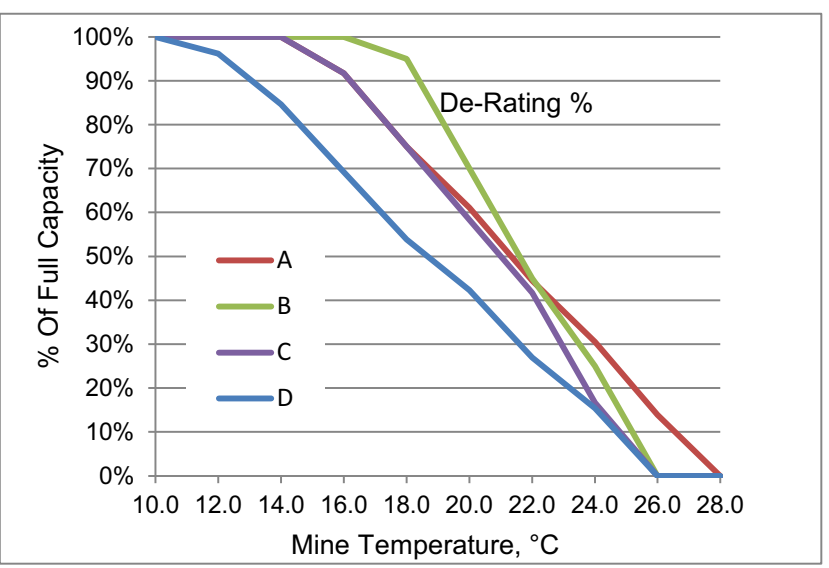

Fig. 5 De-rating of refuge chamber capacity at higher mine ambient temperatures for four different chamber models A through D, modified after Brune [19] 
air quality measurements could be performed accurately inside the chambers.

\subsection{Communications}

Refuge chambers in US coal mines are required to have two separate forms of communication [23]. While in-place mine refuge chambers usually have wired telephone communications installed, portable chambers do not. Furthermore, explosion often damages voice and data communications lines. The ability for miners inside the refuge to communicate with the outside is critical to inform emergency managers about the wellbeing of chamber occupants and their physical and medical needs as well as to inform occupants about the progress of their rescue. If communications are not available, emergency managers will be guessing about the missing miners and miners will increasingly worry about being rescued. In the aftermath of a mine explosion, rescuers may need to drill holes near the locations of all refuge chambers to assess the atmosphere and, by lowering cameras, microphones, and loudspeakers, to determine if chambers had been deployed and are occupied. Still, this may prove inconclusive if direct communication with the miners in the chamber cannot be established. Mines increasingly employ wireless communication systems that are designed to survive explosions and fires, so in the future, portable refuge chambers will need to be tied into the wireless communication networks.

Another method of communication that can be employed is using a microseismic monitoring system. Trapped miners can generate seismic waves by pounding with a hammer on walls, roof, and floor of the chamber, which would then be detected by geophones or similar acoustic sensors. However, seismic wave propagation is greatly affected by strata properties and surrounding noises such as noises on the surface, secondary explosions, and rockfalls. Also, signals produced by trapped miners carry only limited range due to the lack of energy. Therefore, the knockings might not always be detected, in particular when the trapped miner location is located far from the surface. A NIOSH contract project that evaluated SureWave Technology's seismic system for locating trapped miners carried out field tests at two US coal mines [24]. During the field testing at $2 \mathrm{nd}$ site, which is a relatively quiet site, the maximum depth capability of the SureWave system was bracketed to be between about $360 \mathrm{~m}$ $(1200 \mathrm{ft})$ and $470 \mathrm{~m}(1500 \mathrm{ft})$. At the $360 \mathrm{~m}$ depth, with the sensors in contact with the bedrock, the system detected about $20 \%$ of the known pounding cycles, while, at $470 \mathrm{~m}$ depth or with the sensors mounted in topsoil, the system did not detect any pounding cycles. At a depth of $350 \mathrm{~m}(1150 \mathrm{ft})$, in a noisy environment and poor soil coupling of the sensors, the miners' pounding was detected at only 2 out of 7 underground locations and during only 2 out of 18 pounding cycles. Experience during various mine emergencies also confirmed that miners' signals could not be heard, nor located, in most cases.

\subsection{Psychological Stress}

Researchers at NIOSH, a US government agency that focuses on workers' safety and health, point out in publications and training presentations that self-escape from the mine is the primary course of action during an emergency. Brnich et al. [25] outline the difficulty of decision-making when a crew of miners is trapped and contemplates the use of a refuge chamber. In many mine emergency situations, miners know that something is wrong but have limited information even if communication to the surface is still functional. Following a mine explosion of fire, managers at the surface often have less information than those trapped underground. Decision-making is increasingly complex if the decision-making process lacks critical information.

Little if any research has been done to investigate the psychological effects of being sheltered or trapped in a refuge chamber. There are accounts of miners who wrote letters to their loved ones, knowing they might die underground. Figure 6 shows a letter saying goodbye to his family, written by miner Jacob Vowell to his wife, Ellen [26]. Vowell and his son Elbert were among the 216 miners who died in Fraterville coal mine explosion in Tennessee, USA, in 1902.

The letter reads:

We are shut up in the head of the entry with of little air and the bad air is closing in on us fast and it is now about 12 o'clock. Dear Ellen, I have to leave you in bad condition. But dear wife, set your trust in the Lord to help

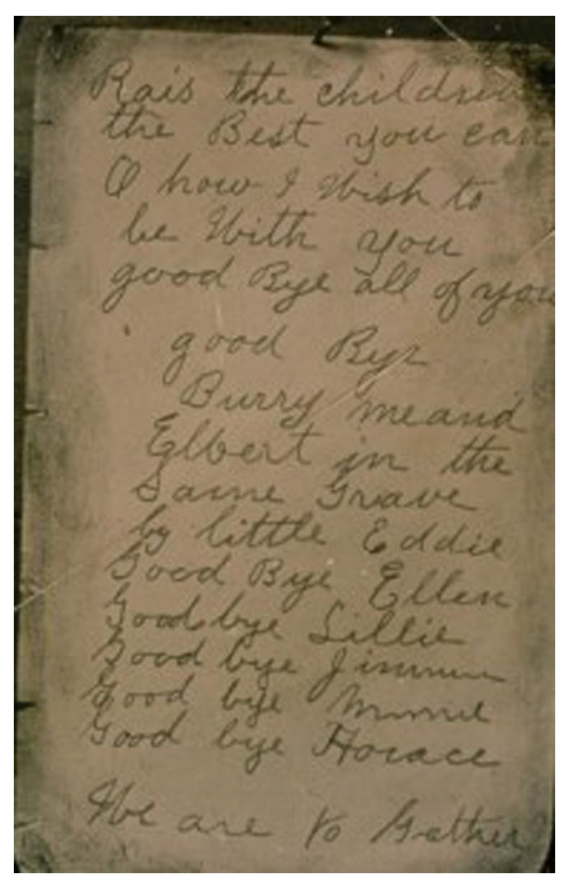

Fig. 6 A page from the good-bye letter written by Jacob Vowell, a miner who was trapped underground and died after the Fraterville Mine explosion in Tennessee, 1902 [26] 
you raise my little children. Ellen take care of my little darling Lily. Ellen, little Elbert said he had trusted in the Lord. Chas. Wood said he was safe if he never lives to see the outside again, he would meet his mother in heaven. If we never live to get out we are not hurt but only perished for air. There is but a few of us here and I don't know where the other men is. Elbert said for you all to meet him in heaven, All the children meet with us both. Ellen, darling Good Bye for us both. Elbert said the lord had saved him. Do the best you can with the children. We are all praying for air to support us but it is getting so bad without any air. Horace, Elbert said for you to wear his shoes and clothing. It is now $1 / 2$ past 1 .

Powell Harmon's watch is now in Andy Woods hand. Ellen, I want you to live right and come to heaven. Rais the children the best you can. O how I wish to be with you. Good Bye to all of you Good Bye. Burry me and Elbert in the same grave by little Eddy.

Good Bye Ellen

Good bye Lillie

Good bye Jimmie

Good bye Minnie

Good bye Horace

We are together. Is $25 \mathrm{~min}$ after Two. There is a few of us are alive yet. Good bye JAKE \& ELBERT

Oh God for one more breath. Ellen, remember me as long as you live. Good Bye Darling"

One can only imagine the agony that miners experience waiting for rescue in a refuge chamber, not knowing if they will be rescued within the $96 \mathrm{~h}$ of life support that the chamber provides. Research is urgently needed to help mining executives, managers, and regulators better understand both the decision-making process involving whether to self-escape or to shelter. Also, researchers need to work on understanding the mental stresses miners experience when they are inside a refuge, awaiting rescue.

\section{Discussion on Self-Escape to the Surface}

When self-escaping to the surface, miners have to don their breathing apparatus to allow them to breathe clean air during the self-escape. Both SCSR and CABA have a limited air supply of, typically $1 \mathrm{~h}$, so miners must changeover to a fresh SCSR or refill the CABA in changeover/refill stations placed along the escape route. Figures 7 and 8 show examples of a SCSR changeover station and a CABA refill station, respectively.

To support this escape strategy, mine safety legislation in the Australian States New South Wales and Queensland, where the majority of underground coal mines in Australia are located, prescribes that all mines must provide at least two trafficable escapeways. Each of them must be segregated from the other, i.e., an incident that occurs in one escapeway does not prevent miners to self-escape in the other escapeway $[29,30]$. This is done by placing stoppings in all crosscuts or cut-throughs that link these two escapeways. Similar regulations are in place for US underground coal mines.

The ability for miners to walk for a long distance in hot, toxic, and smoky atmosphere to safely reach the surface is the main argument against this strategy. In large mines, longwall panels may be 6 to $8 \mathrm{~km}$ long so the distance from the working face to the mine portal can be 10 to $15 \mathrm{~km}$. Even with breathing apparatus, it may not be possible for miners to walk such a long distance especially in a toxic, dust- and smoke-filled atmosphere. Moreover, since an underground coal mine has multiple ventilation splits, travel distances for miners in the aftermath of an explosion may not reach the surface.

The Australian coal industry acknowledges this problem. However, they still believe that self-escaping miners have a better chance of survival compared with those sheltering in a refuge in refuge chambers. Following a fire or explosion, it is likely that mine rescue teams are unable to enter the mine, as happened in the Moura No. 2 and Pike River disasters. To increase the success of the self-escape strategy, coal mines in the State of Queensland participate in annual Level 1 Emergency Exercises [31]. The purpose of these exercises is to test the effectiveness of the mine's
Fig. 7 An example of a SCSR changeover station in underground coal mines [27]
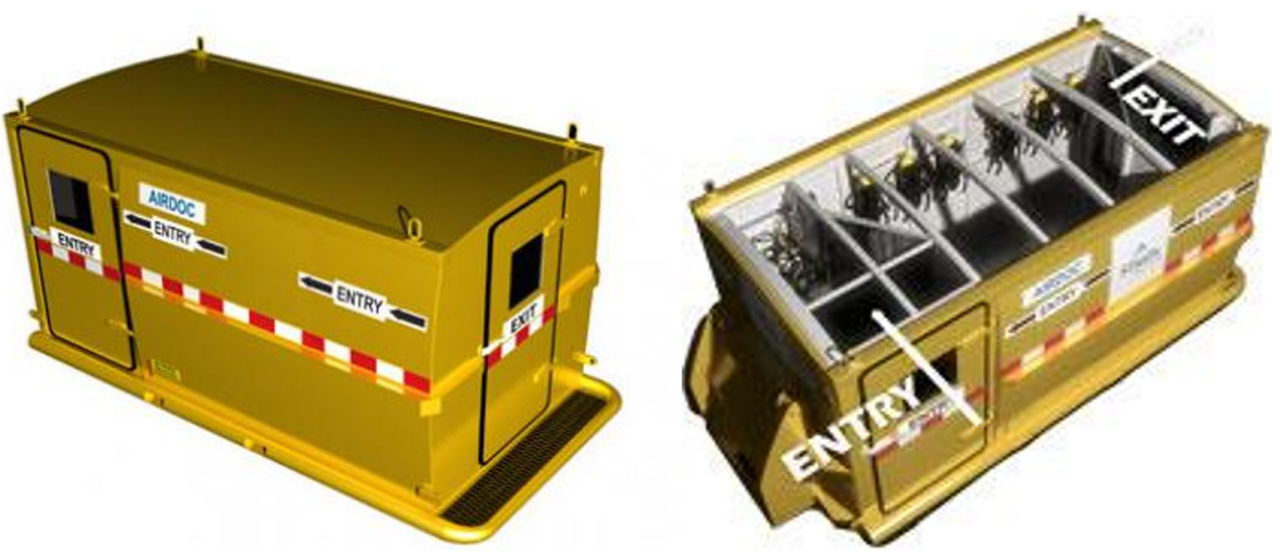


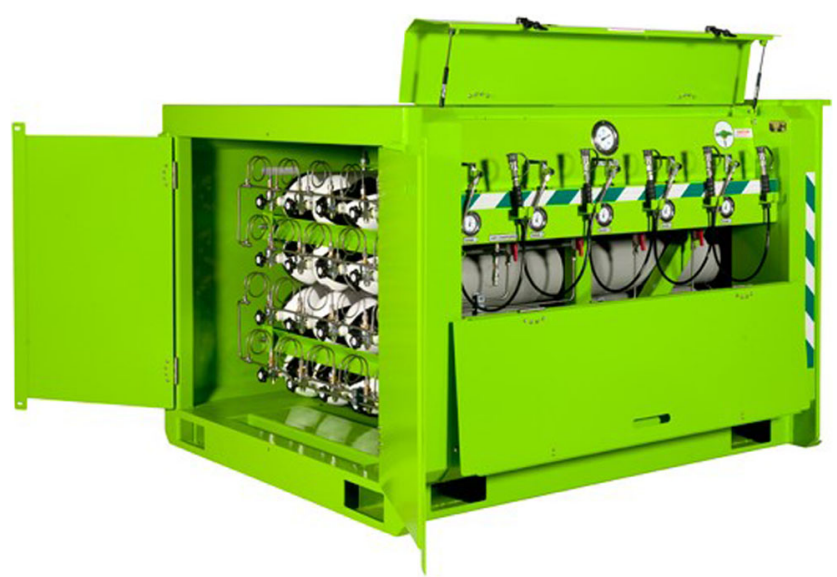

Fig. 8 An example of a CABA refill station in underground coal mines [28]

emergency management system and to practice management and communications during a major emergency. Mines test miners' successfully self-escaping to the surface but also evaluate interaction with external parties such as government agencies, the media, and public. In each exercise, the response to an incident scenario including fires and roof falls is assessed by up to 20 external auditors from government agencies, miners' unions, university researchers, and mining companies. Some scenarios include "injured" and "lost" personnel. The exercises have been running since 1998 and are organized by the Safety and Mines Testing and Research Station (SIMTARS), a Queensland Government agency that carries out research and training on mine safety and health. Major improvements in emergency management have been made due to these exercises, by improving the level of familiarity with SCSR and CABA among miners [32]. Another major improvement is the recognition that the chance of success of the self-escape is greatly enhanced by the provision of motorized transport underground [31,33]. Figure 9 shows an example of a coal mine personnel carrier whose diesel engine meets Australian Standard (AS) 3584.2 for explosion protection. SIMTARS has demonstrated that the diesel engines in these vehicles can be safely operated in methane concentrations over $10 \%$ in air with a minimum oxygen content of $17 \%$ [32]. These diesel engines feature a separate shutoff for air entering the engine as SIMTARS demonstrated that just cutting the fuel may not shut off a diesel engine in a methane-air atmosphere.

\section{Conclusions}

There is still a debate within worldwide coal mining industry about using refuge chambers to manage emergencies in fires or explosions. The Moura No. 2 and Pike River disasters have demonstrated that there is a possibility that the mine rescue teams are unable to enter the mine following a fire or explosion. In these situations, refuge chambers may become useless

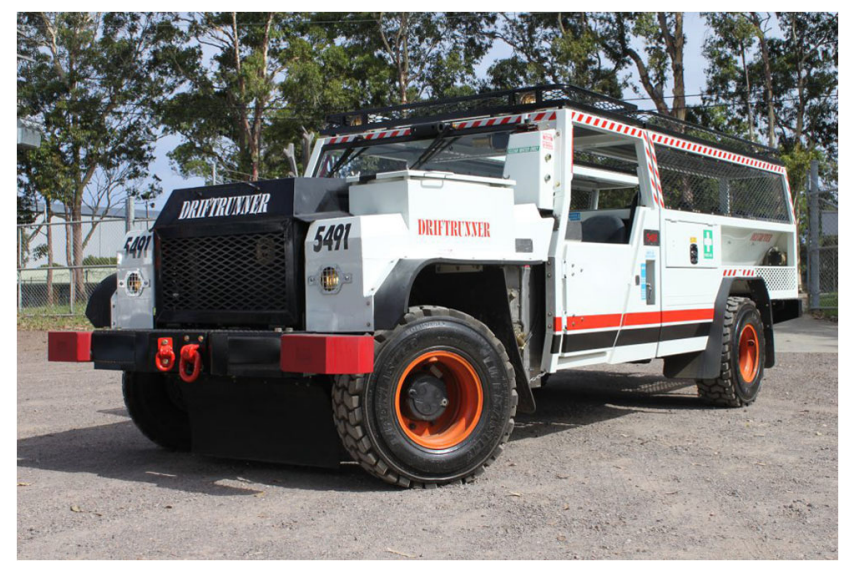

Fig. 9 An Australian coal mine personnel carrier [34]

as mine rescuers may not be able to extract miners who are sheltered in these chambers. In addition, mine refuge chambers may not be useful in highly contaminated atmospheres and may be damaged by mine explosions and fires.

Under these circumstances, self-escape may save more lives than using refuge chambers. Self-escape is further improved by regular training such as Queensland's Level 1 Emergency Exercise. What makes this exercise remarkable is that it is organized by the Government and is assessed mostly by external assessors, which put pressure on mine management to ensure the effectiveness of their emergency management system rather than if the exercise is organized and run internally. This exercise has made major improvements in underground coal mine emergency management since it was started in 1998. It is clear that more improvements will be made during the future exercises.

\section{Compliance with Ethical Standards}

Conflict of Interest The authors declare that they have no conflict of interest.

Open Access This article is distributed under the terms of the Creative Commons Attribution 4.0 International License (http:// creativecommons.org/licenses/by/4.0/), which permits unrestricted use, distribution, and reproduction in any medium, provided you give appropriate credit to the original author(s) and the source, provide a link to the Creative Commons license, and indicate if changes were made.

\section{References}

1. The Guardian newspaper (2014) Terrawatch: The everlasting fire. https://www.theguardian.com/science/2014/aug/01/terrawatcheverlasting-fire. Accessed 29 Aug 2018

2. De Kok D (1986) Unseen danger; a tragedy of people, government, and the Centralia mine fire. University of Pennsylvania Press, Philadelphia, p 17

3. News Limited (2017) Centralia abandoned after coal mine fire began releasing poisonous gas into community. http://www.news. com.au/travel/travel-ideas/weird-and-wacky/centralia-abandoned- 
after-coal-mine-fire-began-releasing-poisonous-gas-intocommunity/news-story/ddbe44db09259a1ef92142a0ec900bff. Accessed 29 Aug 2018

4. Landeshauptstadt Saarbrücken (2018) Brennender Berg. http:// www.saarbruecken.de/tourismus/radfahren und wandern/ wandern/themenwege/brennender_berg. Accessed 29 Aug 2018

5. MineArc (2018a) Hard rock mines refuge chambers. http://minearc. $\mathrm{com} / \mathrm{chambers} /$ minesafe-refuge-chambers/minesafe-standarddesign/. Accessed 29 Aug 2018

6. MineArc (2018b) Coal mines refuge chambers. http://minearc.com/ chambers/coalsafe-refuge-chambers/coalsafe-msha-high-seam/. Accessed 29 Aug 2018

7. Kovac JG et al (1992) Probability of making a successful mine escape while wearing a self-contained self-rescuer. J Int Soc Respir Protect 10(4):8-30

8. Windridge FW (1996) Report on an accident at Moura No 2 underground mine on Sunday, 7 August 1994. https://publications.qld. gov.au/dataset/moura-mining-disaster-inquiry-reports/resource/ a8e96409-52a3-4075-b4a6-b1224ecc8e63. Accessed 29 Aug 2018.

9. Royal Commission on Pike River Coal Mine Tragedy (2012) Report on Pike River Coal Mine Tragedy. http://pikeriver. royalcommission.govt.nz/Final-Report. Accessed 29 Aug 2018

10. West Virginia Office of Miners' Health, Safety, and Training (2006) Report of Investigation Sago Mine Explosion. http://www. wvminesafety.org/sagointerviews.htm. Accessed 29 Aug 2018

11. McAteer JD (2011) Upper Big Branch, The April 5, 2010, explosion: a failure of basic coal mine safety practices. Report to the Governor of the State of West Virginia. http://www.npr.org/ documents/2011/may/giip-massey-report.pdf. Accessed 29 Aug 2018

12. Weiss ES, Cashdollar KL, Harteis SP, Shemon GJ, Beiter DA, Urosek JE (2008) Explosion effects on mine ventilation stoppings. Publication 2009-002, RI 9676. U.S. Department of Health and Human Services, Centers for Disease Control and Prevention, The National Institute for Occupational Safety and Health, DHHS (NIOSH), Pittsburgh, PA, 117 p

13. McMahon GW, Robert Britt J, O’Daniel JL, Kim Davis L, Walker RE (2007) CFD study and structural analysis of the Sago mine accident. Report to the Mine Safety and Health Administration (MSHA)

14. Zipf RK Jr, Sapko MJ, Brune JF (2007) Explosion pressure design criteria for new seals in US coal mines, Information Circular 9500. Department of Health and Human Services, Centers for Disease Control and Prevention, The National Institute for Occupational Safety and Health (NIOSH), Pittsburgh, PA

15. Zipf RK Jr, Gamezo VN, Sapko MJ, Marchewka WP, Mohamed KM, Oran ES, Kessler DA, Weiss ES, Addis JD, Karnack FA, Sellers DD (2010) Methane-air detonation experiments at NIOSH Lake Lynn Laboratory. https://www.cdc.gov/niosh/mining/ UserFiles/works/pdfs/madea.pdf. Accessed 10 May 2019

16. Strebinger C, Bogin GE Jr, Brune JF (2019) CFD modelling of methane flame interaction with simulated longwall coal mine gob. Proceedings of 17th North American Mine Ventilation Symposium. Canadian Institute of Mining, Metallurgy, and Petroleum, Westmount, pp 670-679

17. Page NG, Watkins TR, Caudill SD, Cripps DR, Godsey JF, Maggard CJ, Moore AD, Morley TA, Phillipson SE, Sherer HE, Steffey DA, Stephan CR, Stoltz RT, Vance JW, Brown AL (2011) Report of investigation, fatal underground mine explosion, April 5, 2010, Upper Big Branch Mine-South, Performance Coal Company, Montcoal, Raleigh County, West Virginia. Report No. 46-08436. Mine Safety and Health Administration, Arlington 965 pp

18. Bauer ER, Matty TJ, Thimons ED (2014) Investigation of purging and airlock contamination of mobile refuge alternatives. Publication 2014-116, RI 9694. U.S. Department of Health and
Human Services, Centers for Disease Control and Prevention, The National Institute for Occupational Safety and Health, DHHS (NIOSH), Pittsburgh 61p

19. Brune JF (2012) Dissipating the heat inside mine refuge chambers. Proceedings of 14th North American Mine Ventilation Symposium. The University of Utah, Salt Lake City, pp 297-304

20. Bauer ER, Kohler JL (2009) Update on refuge alternatives: research, recommendations, and underground deployment. SME Annual Meeting and Exhibit, Denver, Colorado, 22 -25 February 2009. Society for Mining, Metallurgy, and Exploration, Littleton, Colorado

21. Steadman RG (1979) The assessment of sultriness. Part I: a temperature-humidity index based on human physiology and clothing science. Journal of Applied Meteorology 18:861-873

22. Yantek DS (2014) Investigation of temperature rise in mobile refuge alternatives. Publication 2014-117, RI 9695. U.S. Department of Health and Human Services, Centers for Disease Control and Prevention, The National Institute for Occupational Safety and Health, DHHS (NIOSH), Pittsburgh $73 \mathrm{p}$

23. Government Publishing Office (GPO) (2010) 30 CFR 7.504 Refuge alternatives and components; general requirements. https://www.govinfo.gov/app/details/CFR-2010-title30-vol1/CFR2010-title30-vol1-sec7-504/context. Accessed 10 March 2019

24. The National Institute for Occupational Safety and Health, DHHS (NIOSH) (2016) Mining contract: development of a seismic system for locating trapped miners. https://www.cdc.gov/niosh/mining/ researchprogram/contracts/contract_200-2011-39885.html. Accessed 26 Feb 2019

25. Brnich MJ Jr, Vaught C, Kowalski-Trakofler KM (2011) Man mountain's refuge: refuge chamber training instructor's guide and trainee's problem book. Publication 2011-195, RI 9685. U.S. Department of Health and Human Services, Centers for Disease Control and Prevention, National Institute for Occupational Safety and Health, DHHS (NIOSH), Pittsburgh 38p

26. The History Blog (2012) The Fraterville mine disaster of 1902. http://www.thehistoryblog.com/archives/16817. Accessed 29 Aug 2018

27. Strata Worldwide (2018) Change over station. http://www. strataworldwide.com/airdoc\%C2\%AE-change-over-station. Accessed 29 Aug 2018

28. Draeger (2018) CABA refill station. https://www.draeger.com/en aunz/Mining/Products/Breathing-Gas-Supply-Systems/DraegerD7000. Accessed 29 Aug 2018

29. Government of New South Wales (2014) Work health and safety (mines and petroleum sites) regulation 2014, regulation 96

30. Government of Queensland (2001) Coal mining safety and health regulation 2001, regulation 296

31. Government of Queensland (2018) Queensland level 1 mine emergency exercise reports. https://publications.qld.gov.au/dataset/ queensland-level-1-mine-emergency-exercise-reports. Accessed 29 Aug 2018

32. Watkinson M (2016) Learning from 18 Level 1 Emergency Exercises. Presentation in Queensland Mining Industry Health and Safety Conference 2016. http://www.qldminingsafety.org.au/ wp-content/uploads/2016/08/Learnings-from-18-Level-1Emergency-Exercises-temp.pdf. Accessed 29 Aug 2018

33. Harrison P, Bell S, Brady D (2010) How will we respond to a mine disaster in 2010? In: Brune JF (ed) Proceedings of Extracting the science - A century of mining research. Society of Mining Engineers-SME, Littleton, pp 314-323

34. VLI (2018) Australian underground coal mine personnel carrier. https://vli.com.au/products/transport-vehicles/mining-vehicles/ flame-proof-diesel-personnel-transport/. Accessed 29 Aug 2018

Publisher's Note Springer Nature remains neutral with regard to jurisdictional claims in published maps and institutional affiliations. 